\title{
Spectrums of depositional practice in later prehistoric Britain and beyond. Grave goods, hoards and deposits 'in between'
}

\author{
Anwen Cooper, ${ }^{\star}$ Duncan Garrow ${ }^{\star \star}$ and Catriona Gibson ${ }^{\star \star *}$ \\ ${ }^{*}$ Cambridge Archaeological Unit, Department of Archaeology, University of Cambridge, Downing Street, Cambridge CB2 \\ 3DZ. Email: ajc1011@cam.ac.uk, ${ }^{*}$ Department of Archaeology, University of Reading, Whiteknights Box 217, Reading, \\ RG6 6AH, UK. Email: d.j.garrow@reading.ac.uk and ${ }^{\star * *}$ Independent scholar. Email: catriona.gibson2@gmail.com
}

\begin{abstract}
This paper critically evaluates how archaeologists define 'grave goods' in relation to the full spectrum of depositional contexts available to people in the past, including hoards, rivers and other 'special' deposits. Developing the argument that variations in artefact deposition over time and space can only be understood if different 'types' of find location are considered together holistically, we contend that it is also vital to look at the points where traditionally defined contexts of deposition become blurred into one another. In this paper, we investigate one particular such category - body-less object deposits at funerary sites - in later prehistoric Britain. This category of evidence has never previously been analysed collectively, let alone over the extended time period considered here. On the basis of a substantial body of evidence collected as part of a nationwide survey, we demonstrate that body-less object deposits were a significant component of funerary sites during later prehistory. Consequently, we go on to question whether human remains were actually always a necessary element of funerary deposits for prehistoric people, suggesting that the absence of human bone could be a positive attribute rather than simply a negative outcome of taphonomic processes. We also argue that modern, fixed depositional categories sometimes serve to mask a full understanding of the complex realities of past practice and ask whether it might be productive in some instances to move beyond interpretively confining terms such as 'grave', 'hoard' and 'cenotaph'. Our research demonstrates that is it not only interesting in itself to scrutinize archaeological evidence that does not easily fit into traditional narratives, but that the process of doing so also sheds new light on the validity of our present-day categories, enabling deeper insights into how people in the past ordered their material and conceptual worlds. Whilst our main focus is later prehistoric Britain, the issues we consider are potentially relevant across all periods and regions.
\end{abstract}

Keywords: Burial archaeology; Bronze Age; Iron Age; ritual; deposition; hoard; cenotaph

\section{Introduction}

Grave goods might be considered the archetypal archaeological find. From the treasures of Tutankhamun's tomb, to the evocative wood shadow of the Sutton Hoo boat burial and the grave goods it contained, to the Amesbury archer and his multi-material 'riches', burials - and the objects caught up within them - have long captured the imagination of archaeologists and the wider public alike. In addition to their ability to evoke interest and somehow capture the romance of archaeological discovery, grave goods have also played a more serious role in the development of archaeological thought. Barrows and the finds within them represented a main focus of early excavation (e.g. Marsden 2011), while 'closed-finds' groups from graves (and hoards) formed the primary basis of the three-age system and Europe-wide metalwork typologies during the mid-19th century (Rowley-Conwy 2007). Throughout the 20th century, grave goods 
continued to play a key role - representing the fulcrum around which numerous culture-historical identifications of 'culture groups' turned (Trigger 2006, 211-314), a key evidence base for New Archaeological and processual models of society (e.g. Binford 1971) and a cornerstone of postprocessual arguments concerning the newly redefined relationships between people, objects, power and identity (e.g. Braithwaite 1984). Objects in graves have continued to play a major role in 21st-century theoretical and methodological developments, forming fundamental evidence sets for innovative interpretive explorations (e.g. Fowler 2013) and highly influential isotopic and aDNA studies (e.g. Parker Pearson et al. 2019; Olalde et al. 2018) alike.

This paper stems from a project investigating the varied roles and meanings of grave goods in later prehistoric (i.e. Neolithic, Bronze Age and Iron Age) Britain. As such, while the issues we consider below are pertinent to discussions in all periods and regions, we focus on later prehistoric Britain as our case-study example. Further information about our data-gathering parameters and methodology can be found in Cooper et al. (2019). Key questions investigated within the paper include the following. How prevalent were body-less object deposits at funerary sites in later prehistory? Were human remains a necessary element of funerary deposits for prehistoric people? Are human remains essential to archaeological identifications of grave goods? Is it possible to develop a more subtle vocabulary for describing and interpreting object deposits, moving beyond interpretively confining and value-laden terms such as 'grave', 'hoard' and 'cenotaph', while also seeking to understand such deposits more specifically than simply as 'ritual'? We begin by illustrating how difficult 'burials' and their associated 'grave goods' can be to define, also demonstrating quite how hazy the boundaries between different depositional contexts often are. We then move on to explore the concept of a 'depositional spectrum', highlighting the value of our approach, which focuses specifically on deposits that are hard to categorize. We look at deposits on funerary sites previously termed 'cenotaphs', body-less 'graves', 'hoards' and other 'ritual deposits', as well as a series of other, newly identified, relevant deposits. A key discussion emerges around the impact that the practice of cremation had on the relationship between bodies and things at this time. We conclude by discussing the validity of contemporary archaeological depositional categories and their relevance to past practices, before moving on to suggest potentially productive future avenues of research.

\section{Defining grave goods}

Despite their critical importance to the history of archaeological thought, grave goods have long proved tricky to define and to interpret satisfactorily. In the early days of archaeology, discussions tended to focus simply on what object types could be found in graves, with the occasional foray into why they may have been included (e.g. Anderson 1883; Mortimer 1905). In recent years, considerations have more frequently concentrated on the latter, often drawing heavily on anthropology for inspiration (Table 1). These more interpretive lists can be very wide-ranging and openended. Writers exploring the various possibilities often end up concluding that it is in fact extremely difficult to decide - on the basis of the archaeological evidence - which of the many possible alternative motivations for including specific objects in graves is most pertinent. As Ekengren $(2013,174)$ simply put it, 'how do we know whether the objects deposited with the deceased were possessions, gifts, offerings, ritual paraphernalia, or ceremonial scrap'? While it is, of course, important that we do consider the many reasons why objects may have been placed in a grave, it generally proves impossible to conclude with any certainty.

The issue of whether all objects within a grave should necessarily be considered 'grave goods' has also been much debated. Examining discussions of this issue from British prehistory and beyond, it becomes clear that certain objects within graves do not always fit everyone's interpretive schemes as to what a 'grave good' should be (Table 2). Items which occupy this ambivalent territory include dress fastenings (which may simply have been worn by the deceased), containers of 
Table 1. Summary of a selection of recent grave good definitions

\begin{tabular}{|c|c|c|}
\hline $\begin{array}{l}\text { Grajetzki } 2014 \\
\text { (late Middle Kingdom Egypt) }\end{array}$ & $\begin{array}{c}\text { Härke } 2014 \\
\text { (early medieval Britain) }\end{array}$ & $\begin{array}{c}\text { Harding } 2016 \\
\text { (later prehistoric Britain) }\end{array}$ \\
\hline Containers for the dead & Equipment for the hereafter & Grave furnishings \\
\hline $\begin{array}{l}\text { Equipment for the journey to the } \\
\text { afterlife }\end{array}$ & Inalienable property & $\begin{array}{l}\text { Personal ornaments and dress } \\
\text { fittings }\end{array}$ \\
\hline $\begin{array}{l}\text { Furnishings for houses in the } \\
\text { afterlife }\end{array}$ & Potlatch & $\begin{array}{l}\text { Indications of rank or status in } \\
\text { society }\end{array}$ \\
\hline $\begin{array}{l}\text { 'Helping hands' for the } \\
\text { afterlife (e.g. servants) }\end{array}$ & $\begin{array}{l}\text { Indicators of rank, status and } \\
\text { identity }\end{array}$ & Funerary accessories \\
\hline Funerary ritual leftovers & Metaphor & Residues from the funerary process \\
\hline $\begin{array}{l}\text { Guardians (for protection } \\
\text { against the living) }\end{array}$ & Remains of the funeral feast & $\begin{array}{l}\text { Tokens of esteem from kin, } \\
\text { clients, etc. }\end{array}$ \\
\hline $\begin{array}{l}\text { Protective objects } \\
\text { (used in life/for the afterlife) }\end{array}$ & Gifts to the deceased & Offerings to supernatural \\
\hline Personal objects & Gifts to a deity & - \\
\hline $\begin{array}{l}\text { Objects preserving the } \\
\text { dead's social identity }\end{array}$ & Disposal of polluted items & - \\
\hline Messages (to the dead) & $\begin{array}{l}\text { Protection of the living } \\
\text { (and the dead?) }\end{array}$ & - \\
\hline Models/miniaturized objects & Forgetting & - \\
\hline
\end{tabular}

Table 2. Ambivalent grave goods

\begin{tabular}{|c|c|c|}
\hline Object category & Excluded as grave goods & Included as grave goods \\
\hline Dress fittings & Nowakowski 1991; Whimster 1981 & - \\
\hline Containers of the dead & Caswell 2013; Kaliff 2005; Wainwright 1967 & - \\
\hline Embedded weapons & Sharples 2010 & - \\
\hline Food from funerary rituals & Grajetzki 2014 & - \\
\hline Objects deposited to protect the living & Grajetzki 2014 & - \\
\hline Pyre goods & McKinley 1997 & - \\
\hline Object fragments & - & Chapman 2000 \\
\hline Human remains (e.g. children) & - & Garwood 2007 \\
\hline
\end{tabular}

cremation burials (e.g. pots), food from associated funerary rituals, weapons embedded within the body, objects that had been burnt along with the body on a cremation pyre, fragments (e.g. pot sherds, waste flint flakes), and even certain categories of human body (e.g. children). Grave goods actually made out of human bone (e.g. Woodward and Hunter 2015, 56) further complicate our categorizations in this regard.

The notion of 'a grave' or 'a burial' in itself can also be hard to pin down (Kaliff 2005). The classic image of a grave - a rectangular hole dug in the earth, with an inhumation at the bottom and objects placed neatly around it - is in fact, at many points in British prehistory especially, a 
relatively rare thing. To note just a few initial illustrative examples, in Neolithic chambered tombs, both objects and (bits of) people were moved in and out regularly, and it is generally very difficult to tell which objects went with which person, and indeed how and why those items came to be in the tomb at all. During the Middle and Late Bronze Age, clearly defined formal burials become rare for long periods in many regions, with fragmented human body parts turning up in a wide variety of locations, including settlement ditches, middens, etc. (Brück 2019, 16-68). During the Iron Age, complete human bodies were placed in disused storage pits in amongst settlement debris and sometimes other 'special' deposits (Sharples 2010, 250-272) - these were clearly 'burials', but were not in a 'grave' as such, and the nature of any links between body and associated material culture is far from straightforward.

On top of these complexities, even in clear-cut 'burials' - where a single body is associated with a group of objects in a neatly defined grave - the link between that person and those objects has been problematized. The well-worn cliché that 'the dead don't bury themselves', as well as the next logical leap, that the objects buried with a person were placed in there by the mourners, not the deceased, has long been recognized. However, whereas once those objects were nonetheless still viewed as directly related to the dead individual's status and identity in life, that relationship has now been questioned by concepts of the 'dividual' and 'distributed personhood' (e.g. Brück 2004; 2019; Fowler 2004) and a generally more critical consideration of people's motivations for having included any objects in a grave (e.g. Barrett 1988; Garrow and Gosden 2012, 194-257; Giles 2012, 91-213; Fowler 2013, 68-107). It can no longer be assumed that any link between the identity/status of the person buried and the objects they were buried with was direct.

'Grave goods', it appears, despite their allure and prominence in so many archaeological narratives, actually represent an especially complex category of archaeological evidence. Once scrutinized in any detail, the concept becomes harder to define. Equally, 'graves' and 'burials' can be tricky to identify and pin down, blurring temporally/spatially/conceptually into other kinds of archaeological context. We argue that in order to understand 'grave goods' - and the acts of deposition they represent - more fully, it is necessary to situate them in relation to a much wider sphere of material-culture deposition. In order to comprehend burials, and indeed hoards, river finds and other 'special deposits', ideally it is necessary to consider the full spectrum of depositional practice together. To our minds, it is difficult for archaeologists to pin graves/grave goods down as a neatly defined category of evidence because people in the past did not themselves necessarily conceptualize these deposits in such a straightforward way. It is therefore important that we incorporate this ambiguity into our interpretations, rather than denying it or forcing it into artificially clear-cut scenarios.

\section{Locating burials: interpretive contexts}

At the outset of this paper, it is perhaps helpful to outline our broad theoretical position. First of all, we feel it is important to investigate humans and non-humans (or objects/animals) on a theoretically equal footing specifically in relation to depositional practice. In so doing, we build loosely on recent 'symmetrical archaeology', which in turn draws on the work of Bruno Latour and others (see Harris and Cipolla 2017, chapter 8 for a concise summary of this literature). Our point is that humans, objects and animals can and perhaps should be viewed as equal components of a range of things that came to be caught up in acts of deposition, including 'burial', throughout prehistory and beyond. Second, drawing on a now fairly substantial body of literature (e.g. Barrett 1991b; Brück 2004; Fowler 2013), we also begin from a standpoint where we make no assumption of a direct relationship between the person (or people) buried in a certain context and the objects buried with them. If we accept this point, especially if also incorporating the previous one, it follows that the material culture within a grave can essentially be treated as interpretively equivalent to the material culture within a hoard, for example: an assemblage of things/people 
that, in this case, included a human body. Third, we want to emphasize that the notion of what a 'grave' or 'burial' context was throughout later prehistory is more fluid than is often acknowledged. As mentioned above, bits of people end up in all sorts of places, associated with a wide variety of depositional (and other) practices. Across all of these, there is a variable relationship between the human objects and the non-human ones. Fourth, we also want to stress that the temporal relationship between a burial/grave and objects meaningfully associated with it can also be varied and extended. For example, an object placed in a grave at the same time as the body could have been made specifically for the funeral (in which case, the person buried would never even have seen it), or an heirloom that was centuries old (in which case many people, including the person buried, may have had a very long-lasting relationship with it). On a subtly different note, the burial and the objects associated with it could have a stretched temporality in other ways as well (with objects relating to the person buried potentially inserted into or on top of the burial later in time).

\section{Spectrums of depositional practice}

It will be clear from what we have said so far that in order to understand grave goods properly we consider it vital to situate them within the broader context of depositional practice across a variety of spheres. In relation to the later prehistory of North West Europe, sustained discussions of hoarding, watery deposits, the intentional deposition of 'single finds' and 'structured deposition' have taken place in recent decades (see Garrow 2012; Bradley 2017; Fontijn 2019 for overviews). Generally speaking, however, deposition in (a) burials, (b) hoards and wet places and (c) monuments and settlements has been discussed separately. Grave goods in particular have often been treated as a distinct and self-evident category of evidence.

In focusing on the traditional interpretive distinction drawn between these different contextual spheres, it is important to stress that they have not always been discussed entirely separately in considerations of prehistoric depositional practice. Two authors in particular - Richard Bradley and David Fontijn - have taken great care to consider them together, and both have constructed convincing and rich narratives by taking multiple depositional contexts into account. Notably, both have examined the burial evidence in relation to hoards/watery deposits primarily in order to understand the latter, mostly within the Bronze Age and mainly focusing on metalwork.

In his book The passage of arms, published in 1990, Bradley undertook the first sustained investigation into votive deposits, focusing mainly on hoards and deposition in watery contexts. His very long-term approach led naturally to a consideration of the ebbs and flows of deposition in different contexts. He noted, for instance, that, as dry-land hoards increased in the later Bronze Age, metalwork in burial contexts declined significantly (Bradley 1998, 97-98). In order to illustrate his point, he used the specific example of daggers. Found almost exclusively in graves during the Early Bronze Age (EBA), their equivalents (dirks and rapiers) are recovered from watery contexts in the M/LBA (ibid., 100) (figure 1). Bradley also considered the possibilities that hoards and river deposits could have been part of a funerary process whereby bodies and their accompanying 'grave' goods were placed in rivers rather than in graves, noting the prevalence especially of skulls in certain rivers, and that hoarding represented a form of conspicuous consumption which over time superseded the placement of metalwork in graves (Bradley 1998, $107,111)$.

Throughout his substantial body of subsequent work, Bradley has developed a number of related ideas, exploring the notion that an object's history may have required certain kinds of deposition at the end of its life (Bradley 2017, 53-54) and comparing the enhanced formality of deposition/arrangement of objects within burials to hoards (ibid., 99). In some of his recent work, Bradley has also touched upon some of the key issues that we want to explore here, suggesting that the distinction drawn between funerary assemblages and hoards has perhaps been 


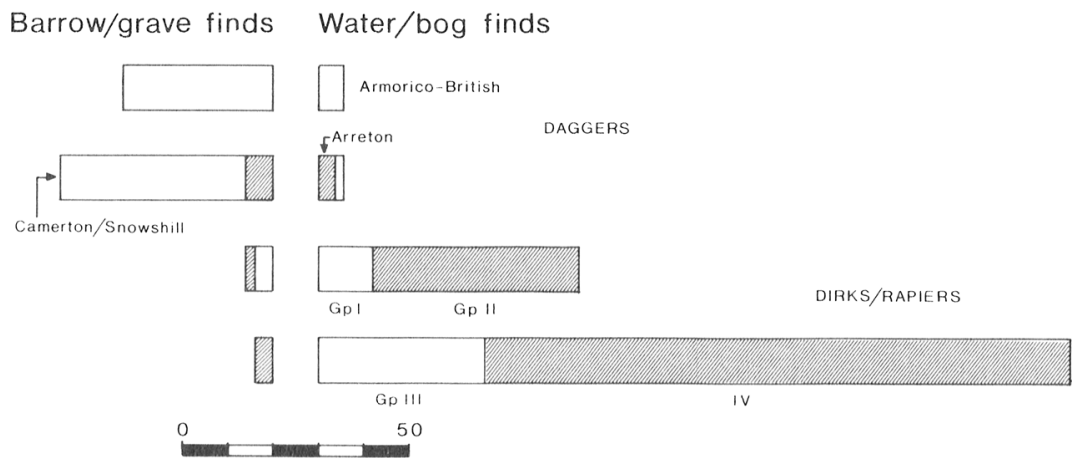

Figure 1. Bradley's illustration of the changing long-term relationship between grave goods and watery deposits (Bradley 1998, figure 20). EBA at the top, M/LBA at the bottom.

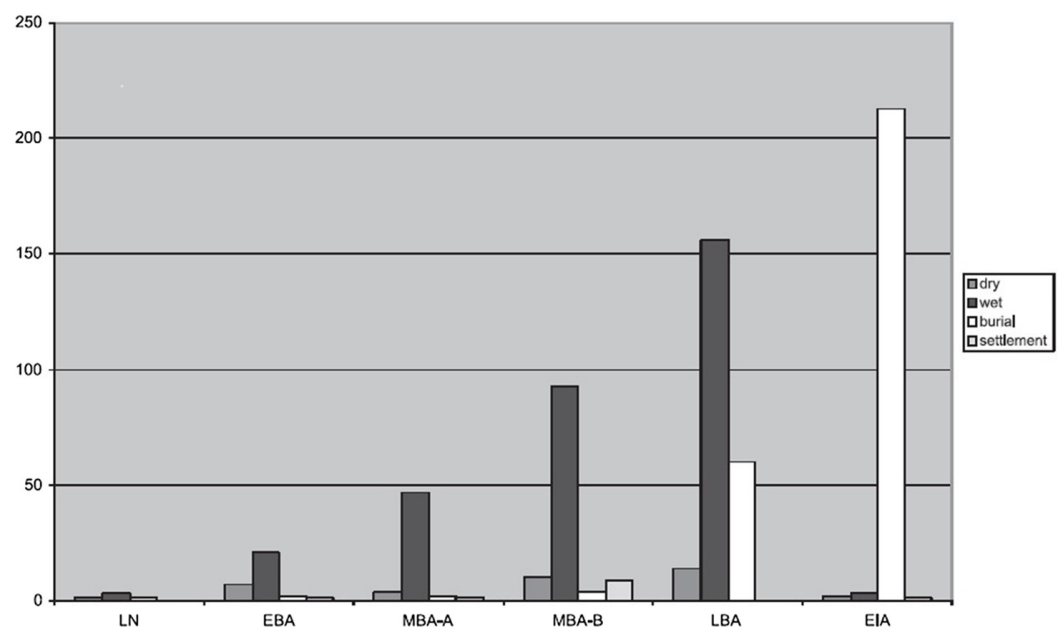

Figure 2. Fontijn's illustration of the changing long-term relationship between depositional contexts of metalwork in the southern Netherlands (Fontijn 2002, figure 10.3).

exaggerated in the past (ibid., 154), and that humans and objects may have been treated as equivalent in varied acts of deposition throughout prehistory (ibid.).

Fontijn's first key work on this subject, Sacrificial landscapes, published in 2002, focused on the deposition of metalwork across a wide range of contexts over the course of the Late Neolithic to Early Iron Age in the southern Netherlands, ca 2300-600 B.C. Like Bradley, Fontijn's long-term focus inevitably led him to investigate the ebbs and flows of deposition in different contexts, and the relationship between these: 'although depositional locations were predominantly wet places, throughout the Bronze Age, other locations were in use as well: dry places, settlements, burials, burial mounds' (Fontijn 2002, 211) (figure 2). Fontijn interpreted differences between contexts as clearly indicative of the 'selective deposition' he was seeking to identify; his basic point was that, in the past, certain objects were considered suitable for deposition in some places but not in others.

Fontijn also considered the possibility that wider metalwork deposits could have been associated with funerary practice, introducing the interesting terms 'graveless grave goods' and 'funeral hoards' to assist in conceptualizing this (ibid., 229-230). Like Bradley, Fontijn understandably concluded that while it is certainly possible that metalwork deposits in rivers and on dry land were part of an extended funerary process (at least in some instances), it is ultimately usually 
impossible to prove this (ibid., 230). Interestingly, he went on to suggest that weapon deposits may have been made in direct association with key rites of passage throughout a person's life, not only in death (ibid., 231). He, too, laid important foundations for key arguments that we wish to make in this paper, perhaps most importantly stressing the need to view all depositional contexts as essentially equivalent and linked, part of one broader phenomenon.

Fontijn updated and extended many of these ideas in his recent Economies of destruction book (2019). Within it, he maintains and reworks a number of key arguments that are relevant here, e.g. "it is essential for depositional studies to not focus on one aspect, like for example "hoards" or "graves" ... but to include evidence from all available contemporary depositional contexts, ranging from settlements to single finds in the landscape' (ibid., 24, italics original). Also relevant to a key argument we make below is his point that 'it is important for archaeologists to not just think of things in terms of their own object categorisations ... but also to be open to the fact that what linked things in the eyes of Bronze Age people may also have been aspects less obvious to us' (ibid., 28).

Work undertaken by others in recent years has also touched on some of the issues we wish to explore: Brück $(2006,300)$ has led the way in breaking down human-object divisions in relation to deposition, stressing, for example, that just as grave goods were given to humans on death, objects could also have been given to houses at key moments in their lives; Garwood (2007) has suggested that some human bodies may have been viewed more as 'grave goods' than as persons in certain burials; Roberts (2007) has viewed the deposition of cremated bone as broadly equivalent to the deposition of many other objects during the Middle Bronze Age; and Joy $(2016,249)$ has discussed Iron Age hoards as possible material expressions of ancestral lineages. Other relevant work (e.g. Jones 2005; Downes 2006; Brück 2019) is discussed further below.

\section{Rethinking spectrums of deposition}

Before turning to our own case studies, we wish to make two key points directly related to the work described above, in order to highlight the interpretive gaps we aim to fill. First, it might be argued that, in studying differential deposition across a range of contexts (e.g. 'hoards', 'burials'), overly clear lines have been drawn around these categories of deposit (see also Fontijn 2019, 136-137). In reality, the distinctions between them - both those created by people in the past, and for us investigating them in the present - are not clear. We are not suggesting that Bradley, Fontijn and others have made an interpretive mistake in seeking to compare these categories - in order to conduct comparative analyses in any archaeological enquiry, it is always necessary to draw hard lines around categories of evidence that are in fact often blurred. Our main point is that it is important to focus on the interstices between categories as well. To develop the 'spectrum' metaphor further, it is interesting and necessary to look at where green turns into blue since the greeny-blue can provide a better understanding of the colours on either side. It is also necessary to remain aware that the different 'colours' of deposition that we define as archaeologists may have been divided up quite differently by people in the past, the arbitrary boundaries between them located elsewhere. In using the colour-spectrum metaphor, it is important to point out that we envisage this not as a linear progression from red to violet, but more fluidly, like a digital colour-choosing palette or colour-space chromaticity diagram where all of the colours can blur into each other.

Our second point is that, in much previous work, the relationship between objects and mortuary practices has not been sufficiently problematized or fully explored. Despite all of the complexities surrounding grave goods and even the definition of 'a burial' noted at the start of this paper, in most discussions of deposition, burial is often treated as a relatively constant or wellunderstood category, against which (less understood) deposits in hoards and watery places are compared. Various authors have raised the suggestion of hoards being 'graveless grave goods', but graves have not been discussed as 'body-ful hoards'. As outlined above, once we treat humans 
and non-humans more symmetrically in deposition, the latter idea becomes much more of a possibility, and our understanding of the make-up of 'different' deposits is altered from the outset.

In the following sections, we focus on a number of related but subtly different 'types' of deposit which clearly - and thus confusingly in terms of our understanding - blur the boundaries between 'grave goods' and other kinds of 'non-mortuary' deposit. In focusing on these hard-to-classify elements of the deposit spectrum, we hope to offer a more in-depth understanding of the whole range of depositional practice in later prehistoric Britain and beyond.

\section{Body-less object deposits at later prehistoric funerary sites}

Given our core project's primary focus on 'grave goods', the case studies below mainly consider object deposits at funerary sites. More specifically, we examine those objects understood to have been associated in some way with funerary activity due to their placement at what are commonly understood to be funerary sites (e.g. round barrows, substantial cemeteries) but which were not directly accompanied by human remains - deposits that have variously been described in the literature as 'hoards', 'burials', 'cenotaphs', 'memorials' or simply 'special/structured/ritual' deposits. This category includes material which resonates closely with contemporary grave deposits in terms of the character of the objects involved and/or the manner in which they were deposited, but it also includes deposits that would more usually be classed as 'hoards' in terms of their artefactual components.

Discussions of 'cenotaphs' or 'memorial burials' are the main arena in which body-less object deposits at funerary sites have been considered previously. One early example of such a discussion is the debate that took place around the turn of the 20th century between antiquarian excavators John Mortimer and Canon William Greenwell over how to interpret grave-like cuts under barrows in East Yorkshire that included no trace of human remains but which sometimes produced objects akin to contemporary grave goods. For example, the central pit beneath Folkton Barrow 249 produced a complete pot and other fragmentary vessels, a flint knife and scrapers, but 'no signs of an interment' (Greenwell 1890, 17). Drawing on the classical term 'cenotaph', Greenwell suggested that barrow mounds were sometimes raised as memorials to people whose bodies could not be interred in the normal way, because they were either lost or buried elsewhere (ibid., 25). Mortimer (1905, xxxviii-ix), meanwhile, was of the opinion that the absence of human remains at barrows was an outcome either of partial excavation (the human remains simply had not been found) or of taphonomic processes (the human remains had rotted away). There are two key points to take from their argument. First, primacy is very much given to human remains - if human remains were not recovered in a funerary monument or grave-like deposit they were considered to be missing, decayed or unidentified; ideally human remains should have been there. Second, this debate highlighted the difficulties of dealing with these deposits interpretively.

More recently, body-less object deposits at funerary sites have been interpreted directly as 'grave' assemblages - i.e. the absence of human remains has been overlooked (e.g. Woodward and Hunter 2015, 232-234) - and as 'hoards' or 'ritual-context deposits', i.e. the inclusion of human remains or 'funerary' context is seen as being of secondary importance (e.g. Needham 2000; 1988; see also Needham 2006). Meanwhile, other more holistic approaches to depositional practices at 'funerary' monuments have avoided these assignations entirely, preferring the terms 'ritual' or 'structured' deposit to describe objects both with and without human remains (e.g. Jones 2005).

The evidence for body-less object deposits at funerary sites across Britain and over the duration of our study period is summarized below. As well as synthesizing published examples, we will broaden out the discussion to include examples that have evaded previous categorization, collected during data gathering for the Grave Goods project. Given that the primary focus of that project was necessarily graves with both human remains and objects, this sample was gathered 
as a side effect of the main exercise and so, while substantial, is not comprehensive. These wider examples serve to illustrate the prevalence of body-less object deposits at funerary sites well beyond prominent published examples and to illuminate elements of this evidence set which have previously received little, if any, analytical attention. Our grouping of the archaeological evidence according to how it was originally interpreted enables us to demonstrate the interpretive variability, complexity and indeed confusion that these deposits have evoked.

\section{Cenotaphs and memorial burials}

Discussions about 'cenotaphs' or 'memorial burials' are the key context in which body-less object deposits at funerary sites have previously been considered. These discussions have cropped up, mainly at the site-specific level and in distinct pulses, over the last 120 years. The examples given here span much of the period 4000 B.C. to A.D. 43 and highlight the diversity of deposits included in this category. At the outset it is important to stress that our main focus here is on identifications of cenotaphs that comprise body-less object deposits at funerary sites rather than on the 'empty' graves or barrows that are also sometimes also described as cenotaphs (e.g. Allen 1981; Downes 2006).

Cenotaphs, as well as 'urns with no bones' which 'may be regarded in some sense as cenotaphs', were defined specifically as formal 'methods of interment' in Grinsell's landmark survey of Bronze Age barrows in Wessex (Grinsell 1941, 100). His specific examples included five interments of 'urns with no bones', and an undisturbed 'cenotaph' grave pit that contained only two pieces of animal bone at Stancombe Barrow 288, Berkshire (Greenwell 1890, 60).

The frequent occurrence of deposits in Middle Bronze Age (MBA) cremation cemeteries in Dorset, which echo contemporary grave deposits (in that they contain upright or inverted pots, sometimes with stone lids, and with varying amounts of charcoal or pyre debris) but include no burnt human bone, was also recognized in the early 20th century. Clay $(1927,469)$ observed that burnt human bone was found in only 56 per cent of the grave pits from the cemetery at Pokesdown (see also Table 3), asserting that this pattern was not simply a product of poor bone survival. Encountering a similar phenomenon at Kinson, Knocker $(1959,145)$ took the interpretation of such deposits one step further, evoking the idea that they were cenotaphs:

Records of empty barrows and pits have commonly been attributed to incompetent excavation in the past. We may wonder, however, whether the burial ritual was ever carried out in the absence of a body. What were the obsequies accorded to a man who was drowned and whose body was swept away by the flood never to be recovered? What rituals commemorated the young child snatched away by wolves?

Twenty years later, during his excavation of the late EBA cairn cemetery at Shaugh Moor, Devon, Wainwright, Fleming and Smith rekindled the idea of cenotaphs. Here no burnt human bone was encountered in the six excavated cairns. Instead, and in keeping with the evidence from Dartmoor more broadly (Jones 2005), most of the cairns were associated with charcoal-filled pits, in one instance (within Cairn 2) containing the base of an upright urn and seven fragmentary faience beads (Wainwright, Fleming and Smith 1979, 26-28) (figure 3). As well as raising the 'cenotaphic rather than mortuary' function of these monuments, and the 'symbolic rather than funerary' significance of the deposit beneath Cairn 2, Wainwright, Fleming and Smith (ibid., 31) emphasized connections between these deposits and contemporary mortuary practices - both locally and more widely (e.g. Griffiths 1960).

In a landmark summary of cenotaph burials - which, interestingly, he described as 'a rare feature of British Prehistory' - Allen $(1981,106)$ drew together a wide range of examples focused initially around evidence from an EBA round barrow at Ravenstone, Buckinghamshire. Here the 
Table 3. Body-less object deposits at MBA cremation cemeteries in Dorset (data from Grave Goods project database)

\begin{tabular}{|c|c|c|c|c|}
\hline Site name & Graves & $\begin{array}{c}\text { Graves with } \\
\text { no human remains }\end{array}$ & $\begin{array}{c}\% \text { graves with } \\
\text { no human remains }\end{array}$ & Reference \\
\hline Simons Ground & 297 & 178 & 60 & White 1981 \\
\hline Pokesdown & - & - & 56 & Clay 1927 \\
\hline Queen's Park, Hadden Hill & 16 & 15 & 94 & Clay 1928 \\
\hline Kinson (Russell Road) & 35 & 24 & 69 & Calkin 1933 \\
\hline Kinson (Caravan Park) & 14 & 8 & 57 & $\begin{array}{l}\text { Hedges, Arnold and } \\
\text { Hedges } 1975\end{array}$ \\
\hline Kinson (Common) & 11 & 5 & 45 & Knocker 1959 \\
\hline Knighton Heath & 60 & 26 & 43 & Peterson 1981 \\
\hline
\end{tabular}

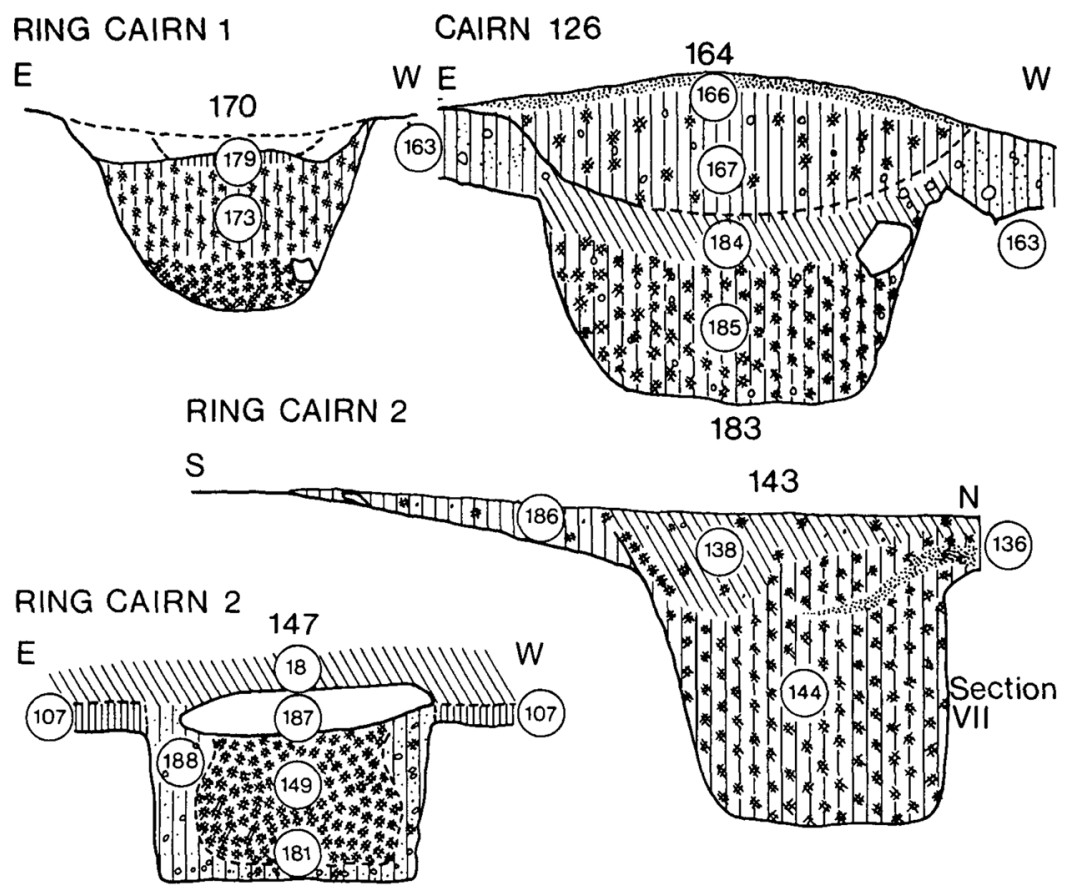

CAIRN 70

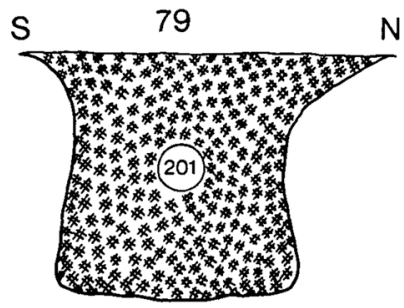

0
CAIRN 70

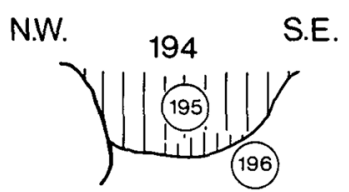

Figure 3. Pit deposits with a 'symbolic rather than funerary significance' from cairns at Shaugh Moor, Dartmoor (Wainwright, Fleming and Smith 1979, figure 12). 


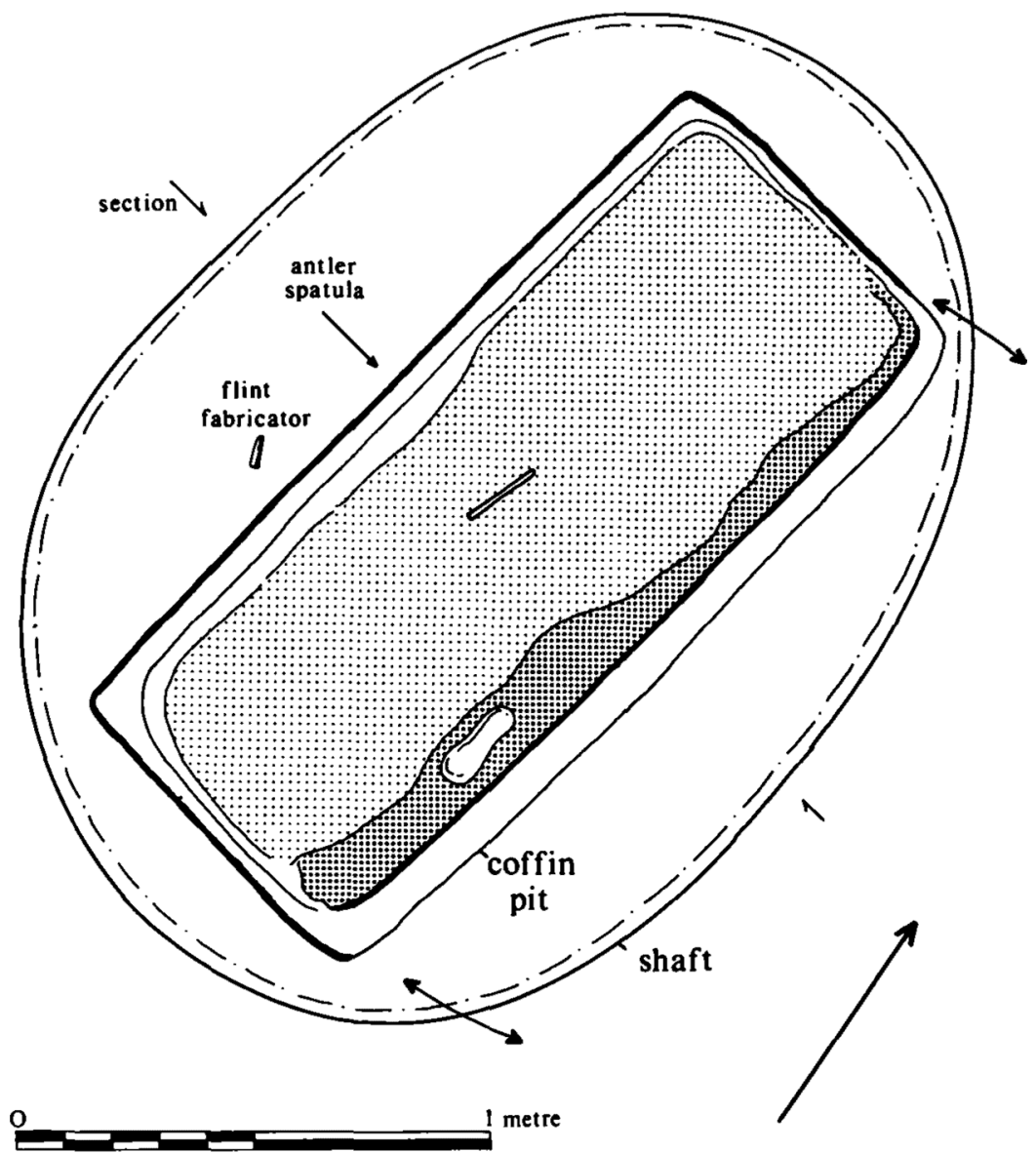

Fig. 5. The primary grave

Figure 4. 'Cenotaph' from the EBA round barrow at Ravenstone, Buckinghamshire (Allen 1981, figure 5).

central grave contained an open wooden coffin but no skeletal material. A fine antler spatula was placed centrally on the coffin base and a flint fabricator perched on the coffin rim (ibid., 106) (figure 4). Tools, together with a beaker pot and a charred plank, were also found with the crouched inhumation burial directly above the 'cenotaph', suggesting that the two deposits may have been linked (ibid., 82). Innovatively for his time, Allen acknowledged the interpretive complexity of the cenotaph deposit, highlighting the importance of considering the social role of rituals surrounding burial practices (ibid., 107-108).

More recent discussions about cenotaphs have arguably been influenced by new theorizations of the cremation burial process (e.g. Barrett 1991b; McKinley 1997). Some studies comparing the make-up of charcoal from grave pits with and without cremated bone, and from nearby settlement features, have also argued convincingly that pyre material was sometimes deposited as 'a proxy for the body' within cremation cemeteries (e.g. O’Donnell 2016). The substantial Late Iron Age (LIA) cremation cemetery at Westhampnett, West Sussex, comprised 161 graves together with pyrerelated features (Fitzpatrick 1997). Burnt human bone was typically deposited within an organic bag placed on the base of grave pits. In at least 13 instances, graves were initially identified based on the presence of charred material and grave goods (mainly pots), but no burnt human bone was actually found (ibid., 71-72). It is also worth noting that on this site, even in graves where human 
bone was found, often only very small quantities were recovered. Based on this evidence, McKinley $(1997,72)$ argued that a distinction should be made between ritual deposits of the dead (graves with substantial quantities of cremated bone) and ritual deposits for the dead (graves with token deposits of, or entirely lacking, cremated bone). Fitzpatrick $(1997,214)$ went further, suggesting that human remains may not even have been an essential element: 'the inclusion of any more than a token quantity of bone, if any bone at all was a matter of choice or custom ... one choice amongst many others in the mortuary rituals'.

Body-less 'graves' The best-known and most spectacular example of a body-less object deposit that has actively been defined as a 'grave' assemblage is at the EBA round barrow at Clandon, Dorset, excavated in the late 19th century (Needham and Woodward 2008). Although the objects recovered there have received considerable recent attention, it is worth highlighting again here their depositional context - as described by Needham and Woodward (ibid., 5) (figure 5). A layer of white clay was spread over existing barrow material; an incense cup was placed directly upon the clay; a flint cairn was built over the incense cup/clay layer which incorporated a number of exceptional objects - a bronze dagger, a gold lozenge, an amber cup, and a composite (shale, jet and gold) macehead. Just 0.3 metre away from this collection (probably above it in the barrow mound), a completely crushed collared urn was deposited on a discrete layer of ash and small flints. No human remains were directly associated with either of these deposits.

In considering the identification of this body-less object deposit as a 'grave' assemblage, a number of points are of interest. Throughout the history of its analysis, there has been uncertainty about how to categorize the Clandon deposit (e.g. Piggott 1938, 102; Needham and Woodward 2008, 1; Jones 2012, 133-134). This ambiguity relates in part to the circumstances in which the assemblage was discovered: the barrow was excavated in 1882 by the antiquarian Edward Cunnington, who made detailed sketches and notes but only wrote these up some 20-25 years later. Discrepancies exist between the written and drawn accounts of the excavation, the barrow was not fully excavated, and there are uncertainties about the precise location of the objects relative to the cairn. However, the absence of directly associated human remains and the sealed nature of the deposit (in the sense that it represents either a discrete event or closely linked series of events) are not really in question (Needham and Woodward 2008, 4-5). The ultimate description of the Clandon deposit as a 'grave' assemblage hinges on the facts that (a) all of the objects involved occur in grave deposits more broadly (although the specific combination of objects is unique), and (b) they were deposited in a monument type that is widely associated with human burial (ibid., 44).

Beyond Clandon, researchers have tended to interpret body-less object deposits at funerary sites as 'graves' implicitly rather than discussing the matter directly. Such deposits are often analysed or described as graves without considering the possibility that the absence of human remains might be a positive attribute of the deposit rather than a negative outcome of taphonomic processes. Piggott's (1938, 102-106) study of 'grave groups' in the Wessex area included several other assemblages where the burial rite is either 'doubtful' or not mentioned explicitly. Wainwright (1967) described the two MBA urn deposits he excavated at Worgret Hill, Dorset, as 'burials' despite the fact that no cremated bone was recovered. White $(1981,42)$ explained the total absence of bone in over half of the 297 urn interments in the MBA cremation cemetery at Simons Ground, Dorset, entirely as an effect of the 'severely acidic' local soils. In doing so he found it difficult to explain why quite substantial quantities of burnt bone did survive in many of the cemetery's interments (ibid., 23), and made no mention of the fact that similar urn deposits lacking human bone are a feature of MBA cremation cemeteries much more broadly in this region (Table 3) (Dacre et al. 1981) and had been understood elsewhere as cenotaphs (see above).

Of course, it is important to acknowledge that many of the E/MBA cremation cemeteries discussed above were excavated some time ago: detailed information about the contents of pottery vessels recovered from these sites is sometimes sketchy. However, the idea that the absence of 

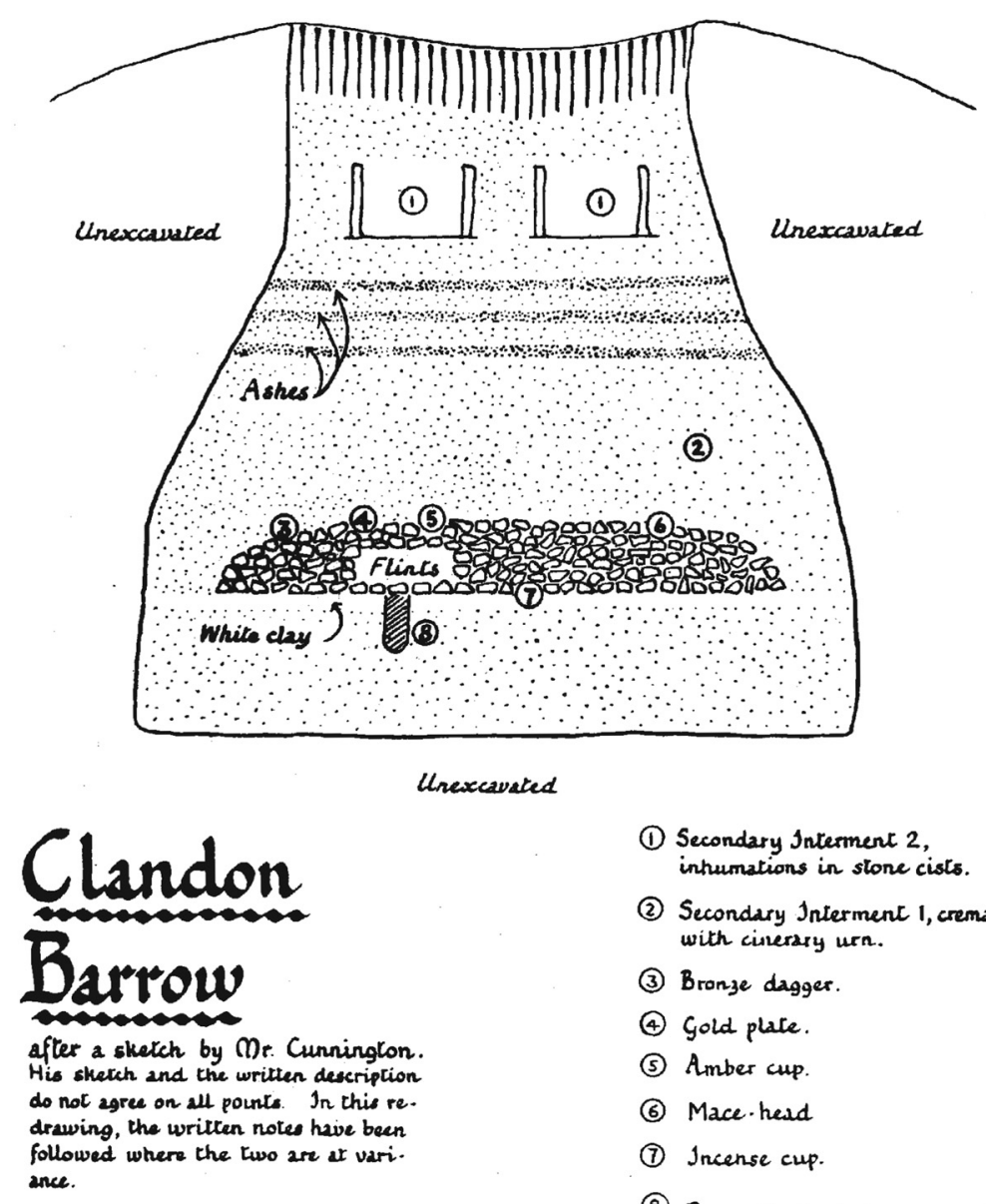

(1) Secondary Interment 2, inturmations in stone cists.

(2) Secondary Interment 1, cremation with cisversy urn.

(3) Bronze dagger.

(4) Gold plate.

(5) Amber cup.

(6) Mace-hesd

(7) Incense cup.

(8) Perpendicular hole, not mentioned in nasrative.

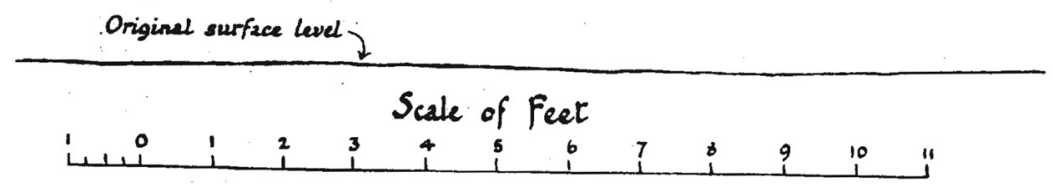

c.D.D.

Figure 5. Section across the EBA round barrow at Clandon, based on a sketch by Edward Cunnington (Drew and Piggott 1936, figure 1).

cremated bone in many of the deposits at these sites cannot be explained straightforwardly by the (often acidic heathland) soils upon which they are located has been raised throughout their period of investigation. The close spatial intermingling of deposits with and without cremated bone at Simons Ground (Ellison 1981) certainly suggests that the lack of bone in some urn deposits was a consequence of human choice rather than simply an outcome of localized patches of higher soil acidity. Equally, at Knighton Heath, Peterson (1981, 181-185) suggested that taphonomy was a contributing factor in the make-up of deposits only to a certain extent, stating clearly that 


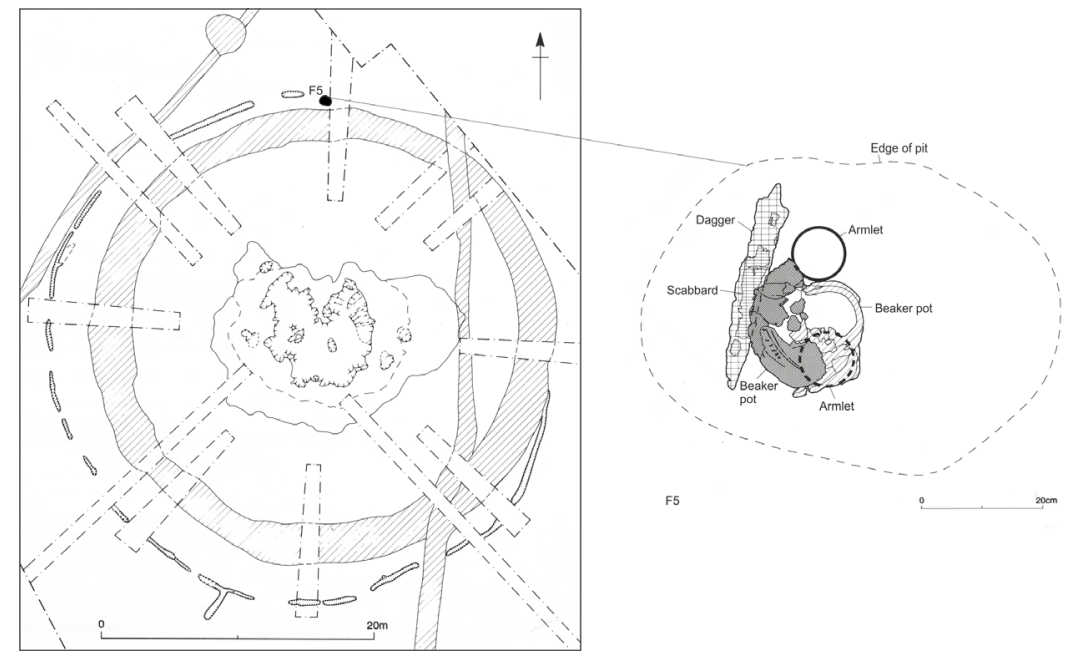

Figure 6. The Lockington Barrow hoard, Leicestershire (Hughes 2000, figures 5, 9).

differential preservation 'cannot account for all the variability in the amount of bone present in different burials' (ibid., 181). It is also worth noting that 'empty urn' and 'token' burials are a regular feature of E/MBA cremation cemeteries across and beyond the Dorset-Hampshire region, including on geologies (e.g. chalk) where bone, if originally present, should have survived (ibid., 208).

Hoards and 'ritual site deposits' Only rarely have body-less object deposits at funerary sites been identified directly as 'hoards'. Since in all cases, however, these include fine metalwork, they are relatively well known. As an extension of our discussion of hoards, we will also examine Needham's (1988) category of 'ritual site deposits' at burial sites. In examining this group it is also important to stress that our primary interest here is in deposits that are broadly contemporary with funerary deposits either at the same site or at other similar sites nearby, not those made in later periods where the linkages become more abstract, for instance the common occurrence of MBA palstave deposits at EBA round barrows (e.g. Cooper 2016).

Of key interest to our discussion is a deposit from the EBA round barrow at Lockington, Leicestershire (Hughes 2000; see also Jones 2012, 131-133). The small, oval pit containing this 'hoard' was located at the northern edge of a multi-phased barrow (figure 6). The western half of the pit contained a remarkable set of objects: a copper dagger and two gold armlets were placed at the base; the lower parts of two nesting beaker pots were inverted over the metal objects, entirely covering one of the armlets. No human remains were found within the pit; the fact that soil phosphate levels were similar within and around the pit supports the idea that no human body was deposited (Hughes 2000, 10). A layer of charcoal spread across the centre of the barrow, which contained flecks of unidentifiable burnt bone and was interpreted as potentially redeposited pyre material (ibid., 99), provides the only hint of EBA funerary activity at Lockington. This 'hoard' is interesting and interpretively elusive on a number of different levels. The objects themselves had complex temporal and spatial histories. While their specific combination is unique, all of the objects from this assemblage are 'very familiar in graves' (Needham 2000, 45). The arrangement of the assemblage within the pit also deserves closer examination. The objects were clustered and in some ways carefully placed - the two armlets were positioned along the length of one side of the dagger - but there is no clear sense that they were organized as if worn on a body.

In interpreting this evidence, Hughes (2000, 101-102) presented several possible scenarios, his preferred option being that this deposit was made during a protracted funerary ceremony comprising various deposits and architectural elements, in which the burial of human remains was not 


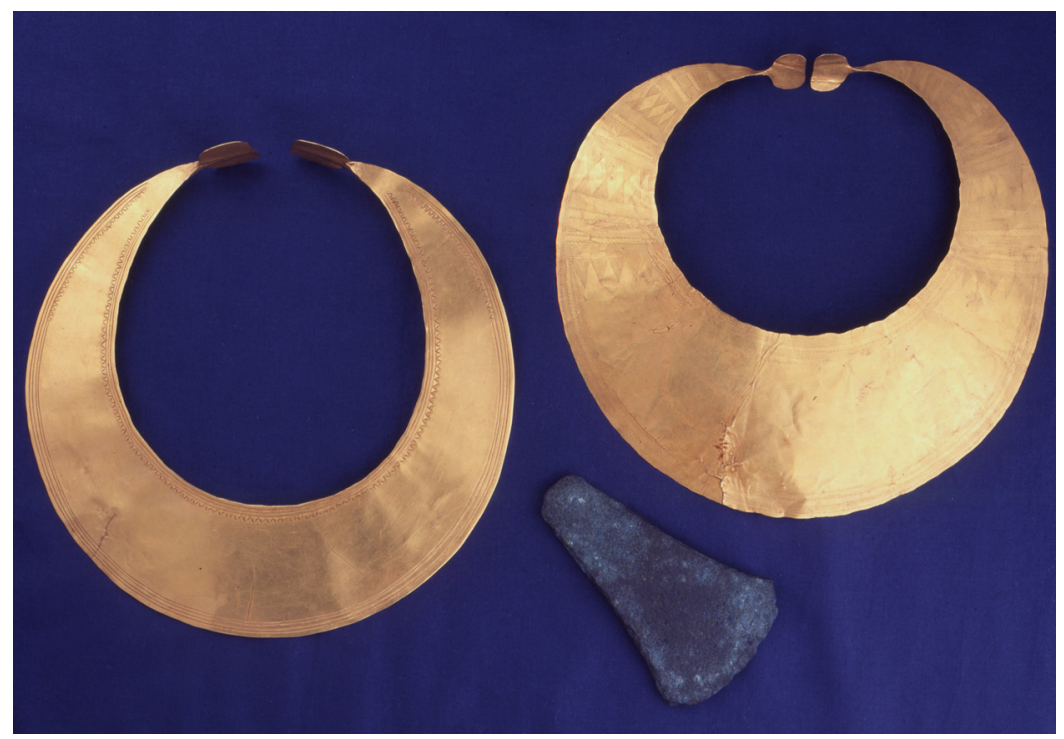

Figure 7. Two lunulae and a flat axe, probably from a barrow mound, at Harlyn Bay, Cornwall (๔ Royal Cornwall Museum).

central. More specifically, Needham viewed the Lockington deposit as a hoard that referred conceptually in its position and content to rites of burial (Needham 2000, 45). Jones $(2012,136)$, too, saw this deposit as analogous to a burial in being designed to "performatively "presence" people in the landscape'.

Further to this specific evidence at Lockington, Needham (e.g. 1988; 2006) has developed his concept of 'ritual-context deposits' over a 20-30-year period through meticulous analysis of many of the valuables found in funerary and other ceremonial contexts. According to Needham's definition, ritual-context deposits mainly constitute hoards and single finds of metalwork deposited at established funerary sites and also occasionally at other ceremonial monuments (e.g. henges), but without human remains. Of the 20 non-grave deposits he identified specifically at burial sites, 17 included at least one axe (or axe mould) (Needham 1988, 241-244) (supplementary material). Probably the best known of this group is the deposit of four flat axes recovered at Willerby Wold, East Yorkshire, from a pit which, like the primary burial at this site, was cut into the contemporary ground surface (Greenwell 1890, 2-5). Beyond non-grave axe deposits at burial sites, Needham $(1988,240$; see also Jones 2005, 38) cited the two gold lunulae probably in a barrow mound at Harlyn Bay, Cornwall (figure 7), and the decorated bronze dagger, tin slag and amber bead fragments scattered across the interior of Caerloggas 1 ring cairn (Miles 1975), also in Cornwall. More recently, Needham has extended this set of 'ritual-context deposits' to include certain 'precious' cup deposits, many of which have been found at funerary sites but have had an ambiguous relationship with any human remains detected (Needham 2006). Needham was initially, and understandably, reticent in asserting definitively how his 'ritual-context deposits' related to mortuary practice, stating that these mound deposits 'may or may not have been buried during funerary rites' (Needham 1988, 243).

'Ritual deposits' at 'ceremonial' sites A more indirect and also more materially inclusive approach to body-less object deposits at funerary sites has generally been taken in contexts where 'valuable' deposits like many of those described above are scarce - in Cornwall, Orkney and Wales, for example (Downes 2006; Lynch 1993, Jones 2005; Miles 1975). In these regions, deposits at barrows, cairns and cists, which sometimes included tiny amounts of cremated human bone, but often did not, have been characterized as forming one of a range of formally deposited 
assemblages. Charcoal, burnt soil, pyre material, clay and quartz chunks/white pebbles are other items that feature often. Some of these deposits also include complete or near-complete pots/ steatite vessels, or other items (amber or faience beads, daggers) that also occur in contemporary cremation burials. On this basis, the more broadly ceremonial, rather than the funerary or cenotaphic, character of these sites has been emphasized (Miles 1975, 74; Lynch 1993, 143; Jones 2005, 140; Downes 2006, chapter 7). Interestingly, Jones (2005) preferred to view all formal deposits encountered at Cornish barrows and cists (including those with human remains) neutrally, simply as different forms of ritual deposit. Meanwhile Downes $(2006,148)$ viewed directly comparable deposits in Orkney as being integral to funerary processes; these may have represented the funerary ceremony at a general level, rather than the dead person/people in particular, with pyre debris, burnt bone and other material being treated in equivalent ways.

Wider evidence for body-less deposits in our own study Given the wealth of examples outlined above, it is perhaps unsurprising that many more comparable body-less object deposits at funerary sites were encountered while creating the Grave Goods project database and in compiling this paper (see the supplementary material). This evidence demonstrates very clearly that body-less object deposits similar to the 'cenotaphs', 'burials', 'hoards', 'ritual site deposits' and 'ritual deposits' already described were a common component of funerary sites across Britain for significant parts of later prehistory.

Amongst this wider evidence set, it is worth summarizing briefly another group of body-less object deposits at funerary sites that is subtly different from the examples given already. In this case, both body-ful and body-less deposits occur at one site, but the temporal relationship between these sets of deposits is unclear. It is possible that the 'liminal' placement of all of these deposits between the realms of the living and the dead - intentionally marks the roles/associations they had in both contexts. Some of the objects may also represent later funeral offerings, perhaps not wholly dissimilar to the bouquets of flowers or associated paraphernalia that are often placed on graves today.

During the EBA in Orkney, objects were often placed on top of the capstones of stone-lined cists, rather than directly accompanying the body. At least 15 incidences have been noted, involving stone axeheads, whetstones and battleaxes. The short cist at Clouduhall, South Ronaldsay, contained an adult cremation burial that was not clearly associated with any grave goods. In the ground beneath this interment, however, was a polished sandstone implement; further exploration revealed a pair of stone slabs, between which were sandwiched a perforated triangular beach pebble and several hundred small shells placed in a concentric pattern (RCAHMS 1946, 288). Similarly, the cremation burial at Mousland, Stromness, was unaccompanied, but an ogival arrowhead and polished steatite axehead were found just outside the cist (Downes 1994a, 141-154).

The covering mounds of Bronze Age barrows and cairns have also frequently been noted to contain significant quantities of material culture (e.g. Kinnes and Longworth 1985; Longworth 1984). In many instances, the precise location and careful placement of objects imply that the deposit could well reference the individuals buried below. In many cases, one particular object category, jet (or lignite/shale) ornaments, predominantly beads and buttons, was employed in this way. For example, at Church Knowle Barrow 7, Dorset, the body of an old adult male was covered with carefully placed chalk blocks, on top of which lay two broken jet or shale pendants (Grinsell 1959, 101), and at Worth Matravers Barrow 3, Dorset, six inhumations in a cist were covered by a thick stone layer, over the top of which broken shale fragments were placed, including part of an armlet (ibid., 160).

M/LBA object deposits comprising complete/near-complete pots filled or mixed in with charcoal/pyre-like material, and placed in pits close to (groups of) unurned cremation burials have been encountered during extensive excavations in Kent and almost certainly occur more widely (e.g. Harding 2001; Ladle and Woodward 2009, 324-325). Similar M/LBA pot deposits also occur 
in isolation and are identified specifically as 'cenotaphs' (see Egging Dinwiddy and McKinley 2009 , for further examples).

In the very different context of MIA East Yorkshire, Rigby's study of the Great Wold Valley cemeteries noted nine instances where pots were placed not in the grave but in barrow ditches. She outlined how 'their condition ... differs little from that of pots buried as grave-goods. It is tempting to see them as having a significant function in burial rites' (Rigby 1991, 109). Rigby did not speculate further. Yet one of the other 'things' that go into such ditches, as well as barrow mounds, is secondary burials, especially infants. It is thus possible that the isolated pots represent a surrogate for another body rather than being a mere token of remembrance for the primary interment.

\section{Discussion}

Categorizing contexts Body-less object deposits at funerary sites disrupt our traditional contextual categories, making us question the nature, validity and fixity of, for example, the terms 'grave good' and 'hoard'. The discrepancy between the two different interpretations of two such deposits from the Early Bronze Age - the Lockington Barrow 'hoard' and the Clandon Barrow 'burial' (described above) - perfectly illustrates the interpretive difficulties of dealing with the depositional spectrum we have outlined. In both cases, without an interpretive space in which to describe and understand the 'greeny-blue' character of these deposits, those discussing each site - despite their clear awareness of the complexities involved - were compelled to couch their interpretations in traditional 'blue' or 'green' terms. Thus, at Lockington, 'the position and content of the hoard [adjacent to a barrow] seems to refer conceptually to rites of burial' (Needham 2000, 45, our emphasis), whilst in the barrow at Clandon, the 'burial [which had no body] ... does not fit into another obvious category such as 'hoard' or some other recurring ritual deposit' (Needham and Woodward 2008, 43, our emphasis). Suspended somewhat awkwardly in between seemingly wellunderstood depositional categories, these body-less object deposits became difficult to comprehend in their own right.

Our suggestion is that, in these cases, and indeed many of the other deposits discussed above, there is a disjunction between the character of past practices and our description/categorization of those practices in the present. It is important that we do not ignore meaningful practices in the past simply because they do not quite fit with our expectations - something that has happened all too often with the body-less object deposits described above. Equally, if we are to describe past practices successfully, we may need to reshape and blur the boundaries between our categories of deposit. This point is illustrated well if we revisit briefly all of the previous categories used to describe body-less object deposits at funerary sites.

The concept of the cenotaph, for example, has undeniably been extremely useful in terms of bringing together what is otherwise an ill-defined and diverse set of deposits. Once it is recognized quite how common body-less object deposits at funerary sites are, however, and what a wide variety of practices they represent, the concept does not feel adequate to explain all of these deposits it seems very unlikely that all of the examples set out above were memorials to people buried elsewhere or otherwise missing. The tactic of describing body-less object deposits at funerary sites as burials in some ways rightly attends to the close relationship between many of these deposits and those which we recognize as formal graves with grave goods. However, usually when the term is applied, the assumption has been that the body was 'missing' during excavation rather than not being essential to the 'burial' in the first place - an approach that we see as untenable. The evidence associated with deposits that have been described as hoards or ritual site deposits at funerary sites confounds our categories further still. The make-up of many of these (e.g. a flat axe inserted into a barrow mound) does appear slightly further removed from that of contemporary burial contexts. This is important, since it emphasizes the likelihood that funerary sites were sometimes a focus for depositional practices beyond human burial. However, the terms 'hoard' and 'ritual site deposit' nonetheless seem insufficient to describe fully the intentions behind the deposition of much 
metalwork (and indeed non-metal objects) at funerary sites. It is impossible to say that 'hoards' and 'ritual site deposits' were not conceptually or temporally related to the 'burials' on those sites in some way: these deposits may well have been referencing their spatial context and its associations - not quite grave goods, they nonetheless can, and in many cases should, probably be termed funerary-related objects. This latter point brings us to our final reflection about past interpretations. In some circumstances, certain writers have preferred to see bodies and objects as equivalent components of ritual deposition, and to remove any necessary expectation that barrows, for example, were funerary monuments at all, preferring instead to see them simply as sites of general ceremonial deposition. Whilst we are in broad agreement with the first 'symmetrical' elements of this argument, we would not want to take the point quite so far - the amalgamation of all acts of deposition (including clear 'burials') into a single 'ritual' original context blurs the depositional spectrum too much, into one homogeneous brown.

Through our investigation of a set of deposits that sits uneasily with existing contextual categories, we have shown the difficulties involved in always maintaining existing analytical distinctions. It is important to stress, however, that we strongly believe that these difficulties should be seen as interpretively productive rather than debilitating. Prehistoric practices were, undoubtedly, sometimes complex and 'blurry' - it should not surprise us that the categories we have developed to understand them are not always flexible enough. Prehistoric people likely defined their world differently to us and these disjunctions provide us with an opportunity to take stock, to reconsider how we might get closer to an understanding of past perceptions, material and social categories, and other aspects of everyday life. As well as identifying 'graves' and 'hoards' (where these simple categories do fit well), it is also important that we consider categories of deposit 'in between' (where relevant) in our interpretations.

Understanding past practice It has long been established that human remains were treated in a complex variety of ways throughout later prehistory in Britain and beyond. The evidence for body-less object deposits at funerary sites set out in this paper suggests that, viewed 'symmetrically' alongside objects, the necessity even to include any physical human remains in 'mortuary' practice was variable, and this was not just because the body was somehow unavailable, as traditional cenotaph interpretations suggest.

The rite of cremation, which ebbs and flows (relative to inhumation and other archaeologically invisible burial rites) throughout our study period, appears key. It is clear from our review of the evidence relating to body-less deposits that the vast majority of these are associated with cremation burial sites, or funerary sites at which cremation burials might have been expected; comparable deposits relating to inhumations (or expected inhumations) are only rarely encountered. In some cases, the deposits we have identified do closely echo contemporary burial practices at the same site (or at comparable sites nearby), such as in the MBA cremation cemeteries in Dorset. In other cases, comparisons are not quite so straightforward, with objects becoming caught up variously in a range of deposits, only a few of which included burnt human bone, as at EBA barrows, cairns and cists in Cornwall and Orkney.

A number of writers have considered the differences between inhumation and cremation in terms of wider associated funerary practices (e.g. Appleby 2013; Barrett 1991b; Brück 2019). It has been noted that cremation potentially lengthened the ceremonial element of burial, extending it both temporally and spatially to multiple sites (e.g. the pyre may have been some distance from the place where the cremated remains were deposited). As a consequence, cremation arguably offered up a greater variety of points in time when material culture could be introduced into the funerary process (e.g. prior to cremation, throughout or immediately after cremation, during burial). Equally, it has also been suggested that the fragmentation of the human body that occurs during cremation may have rendered people into a readily distributable 'resource' that could have been shared between mourners, sometimes leading to only token deposits of bone being placed in the specifically designated 'burial' site (Brück 2019, 32-50). In saying this, however, it is important 
to note that unburnt human bones were similarly fragmented and redistributed on many Neolithic sites where disarticulated inhumations commonly occur; equally, both the excarnation of human bodies and the revisiting of inhumation graves in the Beaker and Early Bronze Age periods (Brück 2019, 56-61; Gibson 2013, 102-106) also offered opportunities for human fragments to be circulated amongst the living as objects, and for 'token' deposits of human remains and separate deposits of funerary-related objects to be made. It is nonetheless important to situate the strong association we have identified between body-less object deposits and cremation burials in relation to these arguments. If we accept that cremation potentially (a) led to chronologically more extended burial practices, (b) introduced more options with regard to the deposition of both body and objects and (c) created new parallels between (distributable) objects and persons, it might be argued that the deposition of objects without a body, but with reference to the funerary associations of a site, is an unsurprising logical next step.

The evidence set out above has also made it clear that objects could potentially have had a 'mortuary' role even when distanced in space and/or time from the deposition of human remains. While it is certainly possible, and in some cases analytically necessary, to view 'grave goods' only as objects directly associated with formal human burials in a grave, it is also clear that funerary deposits of objects extend well beyond this category of evidence and that many of these - especially those that do not include 'valuables' - have been overlooked previously. Thus, we suggest, it is in many circumstances appropriate to discuss a wider category of 'funerary material culture' (including pyre goods, grave goods and other funerary deposits). Where the notion of a 'grave good' deposit does not quite fit, even at a mortuary site, we should not ignore this but interrogate it analytically, allowing interpretive flexibility rather than overlooking evidence or squashing it to fit.

Equally, in relation to the depositional category normally labelled 'hoards', it is clear that this 'type' of deposit can potentially be related to mortuary practice in multiple ways. Sometimes grave-like assemblages were deposited as 'hoards' away from burial sites (e.g. Fontijn's (2002) 'graveless graves'); the manner in which objects were deposited in some 'hoards' can also echo aspects of a burial (e.g. arm rings threaded onto limb-like torcs in the MBA Wylye hoard, Wiltshire (Wilkin 2017, 31)) or may have referenced specific people (Joy 2016, 248). Elsewhere, as we have seen, 'hoard-like' assemblages were deposited at burial sites, occasionally, arguably, even within graves - the collections of jet buttons that accompanied Grave Group 6 at Garton Slack, East Yorkshire (Brewster 1980, 202) and Inhumation A at Harehope Cairn, Peeblesshire (Jobey 1978-1980, 99) might, for instance, be viewed in this way. Again, it becomes clear that 'hoards' and 'grave goods' were not (always) distinct categories. Finally, it might also be said that the spatially separate but conceptually related deposits of human remains and objects represented as LBA 'river finds', for example (as discussed by Bradley (1998) and Fontijn (2002)), arguably seem even more understandable once we consider that this physical separation may actually have originated on the 'funerary' sites themselves.

This paper began by investigating the boundaries of grave goods, demonstrating how, the harder we look, the more difficult the edges of this category become to define. As a broad contextual category, grave goods blur into other kinds of deposit that are tricky to frame - within the depositional spectrum, the green of 'objects in burials' changes into the blue of 'hoards' and yellow of 'settlement debris'. Interestingly, however, this is not by any means always the case - there are many clear-cut deposits that do fit our pre-existing categories. Equally, sometimes, clear patterns are detectable in terms of certain objects being deposited in certain places (e.g. Fontijn 2019). In order to look in detail at one particular blurred category of deposit, and to make our point that it is both important and rewarding to focus analytically on deposits that are hard to define, for the majority of this paper we have focused on body-less object deposits at funerary sites. As a result, the fact that our traditional, standard categories of deposit type/context do not always seem to correlate effectively with past practices and past understandings was made manifest. As a consequence of this realization, we went on to make the points that categories of deposit sometimes require reassessing, and that we must be careful to avoid the tendency to shoehorn the evidence 
we have for prehistoric conceptualizations of the world and unusual (to our minds) practices into modern, preset categories. Grave goods, hoards and other 'types' of deposit are sometimes difficult to define. If we embrace ambiguity when it is present, rather than fighting against it or ignoring it, focusing where necessary on the deposits 'in between', a richer account of the past will emerge.

Acknowledgements. This study was carried out as part of the AHRC-funded Grave Goods: Objects and Death in Later Prehistoric Britain project, a collaboration between the Universities of Manchester and Reading and the British Museum (AH/N001664/1). The Grave Goods project database is available via the Archaeology Data Service: https://doi.org/10. 5284/1052206. Data and regionally specific advice for this research were provided by Cornwall, Dorset, Gwynedd, Humber, Kent, Orkney and the Outer Hebrides Historic Environment Records and by CANMORE. Some of the ideas in this paper were aired initially at the project's Grave Matters conference at the University of Manchester in June 2018; we would like to thank the attendees for several discussions that day which inspired us in developing this topic further. We are grateful to Richard Bradley, David Fontijn, Sharon Gerber/Royal Archaeological Institute, Gwilym Hughes, Clare Randall/Proceedings of the Dorset Natural History and Archaeological Society and the Royal Cornwall Museum for their permission to reproduce images. We would also like to thank a number of colleagues (Richard Bradley, Hella Eckardt, Roberta Gilchrist, Mel Giles, Jackie McKinley, Stuart Needham, Niall Sharples and Neil Wilkin) and the two anonymous reviewers for providing helpful comments on earlier versions of this paper. Finally we would like to acknowledge the broader intellectual inspiration provided by our colleagues on the Grave Goods project, Mel Giles and Neil Wilkin.

Supplementary material. To view supplementary material for this article, please visit: https://doi.org/10.1017/ S1380203820000197

\section{References}

Allen, D., 1981: The excavation of a Beaker burial monument at Ravenstone, Buckinghamshire in 1978, Archaeological journal 138, 72-117.

Anderson, J., 1883: Scotland in pagan times. The Iron Age, Edinburgh.

Andrews, P., P. Booth, A. Fitzpatrick and K. Welsh, 2015: Digging at the gateway. Archaeological landscapes of South Thanet. The Archaeology of East Kent Access (Phase II), Oxford.

Andrews, P., K. Egging Dinwiddy, C. Ellis, A. Hutcheson, C. Phillpotts, A. B. Powell and J. Schuster, 2009: Kentish sites and sites of Kent. A miscellany of four archaeological excavations, Salisbury.

Appleby, J., 2013: Temporality and the transition to cremation in the late third millennium to mid second millennium BC in Britain, Cambridge archaeological journal 23, 83-97.

Barrett, J., 1988: The living, the dead, and the ancestors. Neolithic and Early Bronze Age mortuary practices, in J. Barrett and I. Kinnes (eds), The archaeology of context in the Neolithic and Bronze Age, Sheffield, 30-41.

Barrett, J., 1991a: Handley Barrow 24, in J. Barrett, R. Bradley and M. Green, Landscape, monuments and society. The prehistory of Cranborne Chase, Cambridge, 214-221.

Barrett, J., 1991b: Mortuary archaeology, in J. Barrett, R. Bradley and M. Green, Landscape, monuments and society. The prehistory of Cranborne Chase, Cambridge, 120-140.

Bennett, P., 2008: At the great crossroads. Prehistoric, Roman and medieval discoveries on the Isle of Thanet, 1994-95, Canterbury.

Binford, L., 1971: Mortuary practices. Their study and their potential, in J. Brown (ed.), Approaches to the social dimensions of mortuary practices, Washington, DC, 6-29.

Bradley, R., 1998 (1990): The passage of arms. An archaeological analysis of prehistoric hoards and votive deposits, 2nd edn, Oxford.

Bradley, R., 2017: A geography of offerings. Deposits of valuables in the landscapes of ancient Europe, Oxford.

Braithwaite, M., 1984: Ritual and prestige in the prehistory of Wessex c.2200-1400 BC. A new dimension to the archaeological evidence, in D. Miller and C. Tilley (eds), Ideology, power and prehistory, Cambridge, 93-110.

Brewster, T., 1980: The excavation of Garton and Wetwang Slacks, Wintringham (East Riding Archaeological Research Committee Prehistoric Excavation Report No. 2) (microfiche).

Brück, J., 2004: Material metaphors. The relational construction of identity in Early Bronze Age burials in Ireland and Britain, Journal of social archaeology 4, 307-333.

Brück, J., 2006: Fragmentation, personhood and the social construction of technology in Middle and Late Bronze Age Britain, Cambridge archaeological journal 16, 297-315.

Brück, J., 2019: Personifying prehistory. Relational ontologies in Bronze Age Britain and Ireland, Oxford.

Bushe-Fox, J., 1925: Excavations of the late Celtic urnfield at Swarling, Kent, London.

Calkin, B., 1933: A Late Bronze Age urnfield at Kinson, Dorset, Proceedings of the Dorset Natural History and Archaeological Society 54, 79-86. 
Canterbury Archaeological Trust, 2008: Interim reports on recent work carried out by the Canterbury Archaeological Trust, Archaeologia Cantiana 128, 218-219.

Caswell, E., 2013: Bodies, burnings and burials. Analysing Middle Bronze Age cremations in Britain, unpublished MA dissertation, University of Durham.

Chapman, J., 2000: Fragmentation in archaeology. People, places and broken objects in the prehistory of South Eastern Europe, London.

Christie, P., 1988: A barrow cemetery on Davidstow Moor, Cornwall. Wartime excavations by C.K. Croft Andrew, Cornish archaeology 27, 27-171.

Clay, R., 1927: A Late Bronze Age urn-field at Pokesdown, Antiquaries journal 7, 465-484.

Clay, R., 1928: The excavation of an oval barrow in Hadden's Hill Plantation, Bournemouth, Antiquaries journal 8, 87-89.

Coles, S., S. Hammond, J. Pine, S. Preston and A. Taylor, 2003: Bronze Age, Roman and Saxon sites on Shrubsoles Hill, Sheppey and at Wises Lane, Borden, Kent, Reading.

Colt Hoare, R., 1812: The ancient history of south Wiltshire, London.

Cooper, A., 2016: 'Held in place'? Round barrows in the later Bronze Age of lowland Britain, Proceedings of the Prehistoric Society 82, 291-322.

Cooper, A., D. Garrow, C. Gibson and M. Giles, 2019: Covering the dead in later prehistoric Britain. Elusive objects and powerful technologies of funerary performance, Proceedings of the Prehistoric Society 85, 223-250.

Cunliffe, B., 1987: Hengistbury Head, Dorset, 1. The prehistoric and Roman settlement, 3500 BC-AD 500, Oxford.

Cursiter, J., 1885: Articles exhibited, Proceedings of the Society of the Antiquaries of Scotland 19, 137.

Dacre, M., A. Ellison, R. Everton, I. Smith, S. Davies and J. Richards, 1981: A Bronze Age urn cemetery at Kimpton, Hampshire, Proceedings of the Prehistoric Society 47, 147-203.

Dawkes, G., 2013: Archaeological investigations at the former allotments site, Manston Road Ramsgate, Kent, London (Archaeology South East Report TH/06/0646).

Downes, J., 1994a: Excavation of a Bronze Age burial at Mousland, Stromness, Orkney, Proceedings of the Society of Antiquaries of Scotland 124, 141-154.

Downes, J., 1994b: Linga Fold (Sandwick parish): Bronze Age burial mounds, Discovery and excavation, Scotland, 91-92.

Downes, J., 1999: Orkney Barrows Project, Current archaeology 14, 324-329.

Downes, J., 2006: Cremation practice in Bronze Age Orkney, unpublished Ph.D. thesis, University of Sheffield.

Drew, C., and S. Piggott, 1936: Two Bronze Age barrows, excavated by Mr Edward Cunnington, Proceedings of the Dorset Natural History and Archaeological Society 58, 18-25.

Egging Dinwiddy, K., and J. McKinley, 2009: A potentially mortuary-related deposit at Star Lane, Manton, in P. Andrews, K. Egging Dinwiddy, C. Ellis, A. Hutcheson, C. Phillpotts, A. B. Powell and J. Schuster, Kentish sites and sites of Kent. A miscellany of four archaeological excavations, Salisbury, 81-82.

Ekengren, F., 2013: Contextualizing grave goods, in L. Nilsson Stutz and S. Tarlow (eds), The Oxford handbook of the archaeology of death and burial, Oxford, 173-92.

Ellison, A., 1981: A spatial analysis of the Simons Ground urn cemeteries, in D. White, The Bronze Age cremation cemeteries at Simons Ground, Dorset, Dorchester, 59-64.

Fitzpatrick, A., 1997: Archaeological excavations on the route of the A27 Westhampnett Bypass, West Sussex, 1992, Vol. 2, The Late Iron Age, Romano-British and Anglo-Saxon cemeteries, Salisbury.

Fontijn, D., 2002: Sacrificial landscapes. Cultural biographies of persons, objects and 'natural' places in the Bronze Age of the southern Netherlands, c.2300-600 BC, Leiden.

Fontijn, D., 2019: Economies of destruction. How the systematic destruction of valuables created value in Bronze Age Europe, c.2300-500 BC, London.

Fowler, C., 2004: The archaeology of personhood, London.

Fowler, C., 2013: The emergent past. A relational realist archaeology of Early Bronze Age mortuary practices, Oxford.

Garrow, D., 2012: Odd deposits and average practice. A critical history of the concept of structured deposition, Archaeological dialogues 18, 85-115.

Garrow, D., and C. Gosden, 2012: Technologies of enchantment? Exploring Celtic art 400 BC to AD 100, Oxford.

Garwood, P., 2007: Vital resources, ideal images and virtual lives. Children in Early Bronze Age funerary ritual, in S. Crawford and G. Shepherd (eds), Children and social identity in the ancient world, Oxford, 63-82.

Gibson, C., 2013: Out of time but not out of place. Tempo, rhythm and dynamics of inhabitation in southern England, in A. Chadwick and C. Gibson (eds), Memory, myth and long-term landscape inhabitation, Oxford, 99-123.

Giles, M., 2012: A forged glamour. Landscape, identity and material culture in the Iron Age, Oxford.

Grajetzki, W., 2014: Tomb treasures of the Late Middle Kingdom. The archaeology of female burials, Philadelphia.

Greenwell, W., 1877: British barrows, Oxford.

Greenwell, W., 1890: Recent researches in barrows in Yorkshire, Wiltshire, Berkshire, etc., Archaeologia 52, 1-72.

Griffiths, W., 1960: The excavation of stone circles near Penmaenmawr, North Wales, Proceedings of the Prehistoric Society 26, 303-339.

Grinsell, L., 1941: The Bronze Age round barrows of Wessex, Proceedings of the Prehistoric Society 7, 73-113. 
Grinsell, L., 1959: Dorset barrows, Dorchester.

Harding, D., 2016. Death and burial in Iron Age Britain, Oxford.

Harding, P., 2001: Hengistbury Head Outdoor Education and Field Studies Centre, Salisbury (Wessex Archaeology Report 50092.2).

Härke, H., 2014: Grave goods in early medieval burials. Messages and meanings, Mortality 19, 41-60.

Harris, O., and C. Cipolla, 2017: Archaeological theory in the new millennium, London.

Hedges, J., 1978-1980: Short cists recently excavated at Lower Ellibister and other locations in Orkney, Proceedings of the Society of the Antiquaries of Scotland 110, 49-61.

Hedges, J., C. Arnold and M. Hedges, 1975: Excavation of a barrow and associated urnfield at Fairway Caravan Park, Bournemouth, Rescue archaeology in Hampshire 3, 5-34.

Hedges, M., 1979: The excavation of the Knowes of Quoyscottie, Orkney. A cemetery of the early first millenium BC, Proceedings of the Society of Antiquaries of Scotland 108, 130-155.

Hughes, G., 2000: The Lockington gold hoard. An Early Bronze Age barrow cemetery at Lockington, Leicestershire, Oxford.

Hurd, H., 1911: Some notes on recent archaeological discoveries at Broadstairs, Broadstairs.

Jessup, R., 1930: The archaeology of Kent, London.

Jobey, G., 1978-1980: Green Knowe unenclosed platform settlement and Harehope Cairn, Peeblesshire, Proceedings of the Society of Antiquaries of Scotland 110, 72-113.

Jones, A., 2004-2005: Settlement and ceremony. Archaeological investigations at Stannon Down, St Breward, Cornwall, Cornish archaeology 43-44, 1-140.

Jones, A., 2005: Cornish Bronze Age ceremonial landscapes c.2500-1500 BC, Oxford (BAR British Series, 394).

Jones, A.M., 2012: Prehistoric materialities. Becoming material in prehistoric Britain and Ireland, Oxford.

Joy, J., 2016: Hoards as collections. Re-examining the Snettisham Iron Age hoards from the perspective of collecting practice, World archaeology 48(2), 239-253.

Kaliff, A., 2005: The grave as concept and phenomenon, in T. Artelius and F. Svanberg (eds), Dealing with the dead, Stockholm, 125-142.

Kinnes, I., and I. Longworth, 1985: Catalogue of the excavated prehistoric and Romano-British material in the Greenwell Collection, London.

Knocker, G., 1959: Excavation of three round barrows at Kinson, near Bournemouth, Proceedings of the Dorset Natural History and Archaeological Society 80, 133-145.

Ladle, L., and A. Woodward, 2009: Excavations at Bestwall Quarry, Wareham 1992-2005, Dorchester.

Longworth I., 1984: Collared urns of the Bronze Age in Great Britain and Ireland, Cambridge.

Lynch, F., 1971: Report on the re-excavation of two Bronze Age cairns in Anglesey. Bedd Branwen and Treiorwerth, Archaeologia Cambrensis 120, 11-83.

Lynch, F., 1991: Prehistoric Anglesey. The archaeology of the island to the Roman conquest, 2nd edn, Llangefni.

Lynch, F., 1993: Excavations in the Brenig valley. A Mesolithic and Bronze Age landscape in North Wales, Welshpool.

McKinley, J., 1997: Bronze Age 'barrows' and funerary rites and rituals of cremation. Proceedings of the Prehistoric Society 63 , 129-145.

Marsden, B., 2011: The early barrow diggers, Stroud.

Mattingley, J., J. Marley and A. Jones, 2009: Five gold rings? Early Bronze Age gold lunulae from Cornwall, Cornish archaeology 48, 95-114.

Miles, H., 1975: Barrows on the St Austell granite, Cornwall, Cornish archaeology 14, 5-82.

Mortimer, J., 1905: Forty years' researches in British and Saxon burial mounds of East Yorkshire, London.

Needham, S., 1988: Selective deposition in the British Early Bronze Age, World archaeology 20, 229-248.

Needham, S., 2000: The gold and copper metalwork, in G. Hughes, The Lockington gold hoard. An Early Bronze Age barrow cemetery at Lockington, Leicestershire, Oxford, 23-47.

Needham, S., 2006: Precious cup. Concept, context and custodianship, in S. Needham, K. Parfitt and G. Varndell (eds), The Ringlemere cup. Precious cups and the beginning of the Channel Bronze Age, London, 69-73.

Needham, S., and A. Woodward, 2008: The Clandon Barrow finery. A synopsis of success in an Early Bronze Age world, Proceedings of the Prehistoric Society 74, 1-52.

Newall, R., 1927-1929: Two shale cups of the Early Bronze Age and other similar cups, Wiltshire archaeological magazine 44, 111-117.

Nowakowski, J., 1991: Trethellan Farm, Newquay. The excavation of a lowland Bronze Age settlement and Iron Age cemetery, Cornish archaeology 30, 5-242.

Nowakowski, J., 1995: The excavation of a complex barrow at Trelowthas Manor Farm, Probus 1995, Cornish archaeology 34, 206-211.

O'Donnell, L., 2016: The power of the pyre. A holistic study of cremation focusing on charcoal remains, Journal of archaeological science 65, 161-171.

Olalde, I., S. Brace, ... D. Reich, 2018: The Beaker phenomenon and the genomic transformation of Northwest Europe, Nature 555, 190-196. 
Parker Pearson, M., A. Sheridan, M. Jay, A. Chamberlain, M. Richards and J. Evans, 2019: The Beaker People. Isotopes, mobility and diet in prehistoric Britain, Oxford.

Peterson, F., 1981: The excavation of a Bronze Age cemetery on Knighton Heath, Dorset, Oxford (BAR British Series, 98).

Piggott, S., 1938: The Early Bronze Age in Wessex, Proceedings of the Prehistoric Society 4, 52-106.

Piggott, S., and C. Piggott, 1944: Excavation of barrows on Crichel and Launceston Downs, Dorset, Archaeologia 90, 47-80.

Pitt-Rivers, A., 1888: Excavations in Cranborne Chase, near Rushmore, on the borders of Dorset and Wiltshire, Vol. 2, London.

Pitt-Rivers, A., 1892: Excavations in Cranborne Chase, near Rushmore, on the borders of Dorset and Wilts, London.

Powell, A., 2015: Archaeological discoveries along the Farningham to Hadlow gas pipeline, Kent (Wessex Archaeology Project 70304), at www.kentarchaeology.org.uk/10/00.htm. Accessed 2.1.20.

RCAHMS (Royal Commission of Ancient and Historic Monuments), 1946: Twelfth report with an inventory of the ancient monuments of Orkney and Shetland, Vol. 1, Orkney, Edinburgh.

Rigby, V., 1991: The pottery, in I. Stead, Iron Age cemeteries in East Yorkshire, London, 94-118.

Roberts, B., 2007: Adorning the living but not the dead. A reassessment of Middle Bronze Age ornaments in Britain, Proceedings of the Prehistoric Society 73, 135-167.

Rowley-Conwy, P., 2007: From Genesis to prehistory. The archaeological three age system and its contested reception in Denmark, Britain and Ireland, Oxford.

Russell, V., 1971: West Penwith survey, Truro.

Seager Smith, R., and A. Woodward, 2000: Pottery, in K. Walker and D. Farwell (eds), Twyford Down, Hampshire. Archaeological investigations on the M3 motorway from Bar End to Compton, 1990-93, Winchester, 46-78.

Sharman, P., 2007: Excavation of a Bronze Age funerary site at Loth Road, Sanday, Orkney, Scottish archaeological internet reports 25, at https://doi.org/10.5284/1017938. Accessed 2.1.20.

Sharples, N., 2010: Social relations in later prehistory, Oxford.

Smith, G., 2006: An Early Bronze Age cremation cemetery at Blaen y cae, Bryncir, Garndolbenmaen, Archaeology in Wales 46 , $11-20$.

Stead, I., 1986: A group of Iron Age barrows at Cowlam, North Humberside, Yorkshire archaeological journal 58, 5-15.

Stevens, S., 2003: Archaeological investigations at Hawkinge Aerodrome, Hawkinge, Kent, London (Archaeology South East Report 677), available at https://doi.org/10.5284/1027396 (accessed 2 January 2020).

Sumner, H., 1922: Excavation of barrows on Ibsley Common, Transactions of the Bournemouth Field Club and Archaeological Society 14, 69-78.

Trigger, B., 2006: A history of archaeological thought (2nd edn), Cambridge.

Wainwright, G., 1967: Excavation of a round barrow on Worgret Hill, Arne, Dorset, Proceedings of the Dorset Natural History and Archaeological Society 87, 119-125.

Wainwright, G., A. Fleming and K. Smith, 1979: The Shaugh Moor Project. First report, Proceedings of the Prehistoric Society 45, 1-33.

Walker, K., and D. Farwell (eds), 2000: Twyford Down, Hampshire. Archaeological investigations on the M3 motorway from Bar End to Compton, 1990-93, Winchester.

Warne, C., 1866: The Celtic tumuli of Dorset. An account of personal and other researches in the sepulchral mounds of the Durotriges, London.

Wessex Archaeology, 2008: Archaeological investigations at Springhead Quarter (Phase II). Northfleet, Kent. Archaeological assessment report and updated project design, Salisbury.

Whimster, R., 1981: Burial practices in Iron Age Britain. A discussion and gazetteer of the evidence c.700 BC-AD 43, Oxford (BAR British Series, 90).

White, D., 1981: The Bronze Age cremation cemeteries at Simons Ground, Dorset, Dorchester.

Wilkin, N., 2017: Combination, composition and context. Readdressing British Middle Bronze Age ornament hoards (c.14001100 cal. BC), in T. Martin and R. Weetch (eds), Dress and society. Contributions from archaeology, Oxford, 14-47.

Woodward, A., and J. Hunter, 2015: Ritual in Early Bronze Age grave goods, Oxford.

Cite this article: Cooper A, Garrow D, and Gibson C (2020). Spectrums of depositional practice in later prehistoric Britain and beyond. Grave goods, hoards and deposits 'in between'. Archaeological Dialogues 27, 135-157. https://doi.org/10.1017/ S1380203820000197 